Mitteilungen der Österreichischen Geographischen Gesellschaft, 160. Jg., S. 303-329

(Annals of the Austrian Geographical Society, Vol. 160, pp. 303-329)

Wien (Vienna) 2018, https://doi.org/10.1553/moegg160s303

\title{
City Divided: Place Names and Nationalism IN THE CZECh-Polish BorderLandS ${ }^{1)}$
}

\author{
Přemysl MÁCHA, Horst LASSAK, and Luděk KRTIČKA, \\ all Ostrava (Czechia)* \\ Initial submission / erste Einreichung: 02/2018; revised submission / revidierte Fassung: 09/2018; \\ final acceptance / endgültige Annahme: 12/2018 \\ with 1 figure and 5 tables in the text
}

\section{CONTENTS}

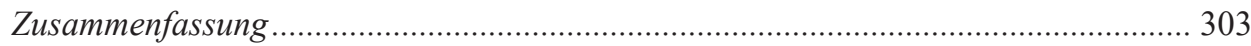

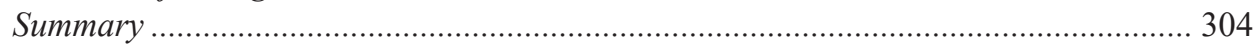

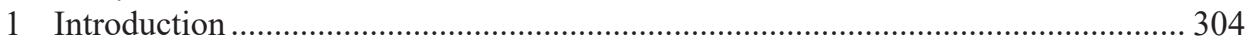

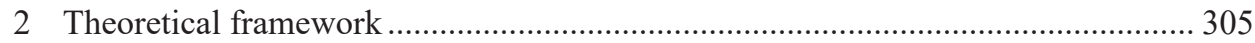

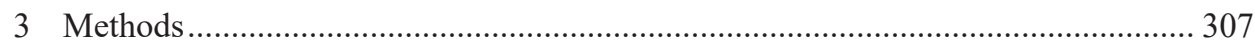

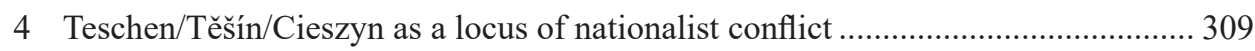

5 The politics of toponymy and the urban space................................................... 313

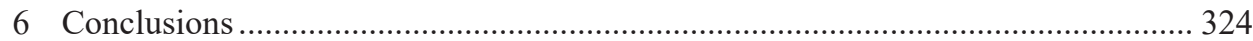

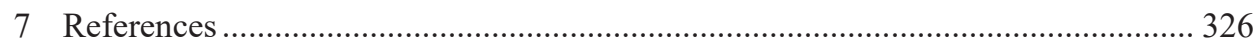

\section{Zusammenfassung}

\section{Die Geteilte StADt - ORTSNAMEN Und NATIONALiSMUS IM TSCHECHISCH- POLNISCHEN GRENZGEBIET}

In unserem Artikel analysieren wir die Rolle von Ortsnamen bei der Konstruktion nationaler Identitäten im tschechisch-polnischen Grenzgebiet. Die analysierten Städte sind Český Těšin, Tschechien, und Cieszyn, Polen - Städte, die nach der Teilung der ursprünglichen österreichisch-schlesischen Stadt Teschen zwischen den neu gegründeten Staaten Tschechoslowakei und Polen im Jahr 1920 entstanden sind. Mit offiziellen Karten, ArchivDokumenten, Interviews und mithilfe von GIS analysieren wir die Transformationen der

1) This work was supported by the Czech Science Foundation (grant number 6-34841L) and the Austrian Science Fund (grant number I 2366-G23).

* PhDr. Přemysl Mácha Ph.D., Mgr. Horst LassaK, and Mgr. Luděk KrtičKa, Department of Human Geography and Regional Development, Faculty of Science, University of Ostrava, Chittussiho 10, CZ-71000 Ostrava, Czechia; emails: premysl.macha@osu.cz; lassak.horst@gmail.com; ludek.krticka@osu.cz 
toponymischen Landschaft auf beiden Seiten der Staatsgrenze im 20. Jahrhundert und identifizieren Haupttrends und signifikante Unterschiede in verschiedenen Perioden und auf verschiedenen Seiten der Grenze. Wir zeigen, wie österreichischer, deutscher, tschechischer, polnischer und schlesischer Nationalismus - im Wettbewerb untereinander und mit anderen Ebenen der Gruppenidentifikation und anderen politischen Ideologien - strategisch Ortsnamen verwendet hat, um eine eindeutige nationale Identifikation der Stadtbewohner in einer Region von großer historischer, ethnischer und politischer Komplexität zu fördern.

Schlagwörter: Ortsnamen, Identität, Nationalismus, Teschen, Český Těšín, Cieszyn, Schlesien, Tschechien, Polen

\section{Summary}

In our article we analyse the role of place names in the construction of national identities in the Czech-Polish borderlands. The analysed cities are Český Těšin, Czechia, and Cieszyn, Poland, cities which were created after the division of the original Austrian Silesian city of Těšin/Cieszyn/Teschen between the newly established states of Czechoslovakia and Poland in 1920. Using official maps, archival documents, interviews, and GIS we analyse the transformations of the toponymic landscape on both sides of the state border during the $20^{\text {th }}$ century, identify principal trends and significant differences in different periods and sides of the border, and show how Austrian, German, Czech, Polish and Silesian nationalism - in competition with each other and with other levels of group identification and other political ideologies - have strategically used place names to promote a clear national identification of the city inhabitants in a region of great historical, ethnic and political complexity.

Key words: Place names, identity, nationalism, Teschen, Český Těšin, Cieszyn, Silesia, Czechia, Poland

\section{Introduction}

In the last two decades, place names have become an important object of interest for cultural anthropologists and human geographers. This is because of the growing awareness of place names' fundamental association with identity and power. A number of recent studies have shown the role of place names in place-making, the construction and promotion of national and other group identities, and the legitimisation of competing political regimes (see e.g. Azaryahu 1996; Alderman 2000; Light 2004; Gill 2005; Palonen 2008). The significance of place names becomes particularly visible during periods of major political and ethnic change when new regimes and newly dominant ethnicities attempt to reinscribe the toponymic landscape in order to secure their legitimacy as well as their material and intellectual control.

In our article, we focus on precisely such a threshold situation. Our case study is the twin city of Český Těšín, Czechia, and Cieszyn, Poland, in the Czech-Polish borderlands. 
This small but historically important regional town located in the Austrian part of Silesia in times of the Austrian-Hungarian Monarchy and called Teschen by its dominant German-speaking population underwent a profound transformation during the turbulent twentieth century, resulting in its separation into two separate border towns with a dominant Czech and Polish population after the formation of independent Czechoslovakia and Poland. Complex ethnic relations have marked its history and influenced heavily the politics of toponymy documented by the historic sources, linguistic landscape and present-day memory.

It is an excellent opportunity to document the significance of place names for identity formation and ethnic relations while providing new information on the impact of nation-state (geo-)politics on the toponymic landscape in small towns with a strong presence of ethnic and linguistic minorities. After a brief discussion of the current approaches to place-names in geography and anthropology and an equally brief historical characterisation of the studied area, we describe and analyse the transformations of the toponymic landscape on both sides of the state border during the $20^{\text {th }}$ century, identify principal trends and significant differences in different periods and sides of the border, and show how Austrian, German, Czech, Polish and Silesian nationalism - in competition with each other and with other levels of group identification and other political ideologies - have strategically used place names to promote a clear national identification of the city inhabitants in a region of shifting borders and great historical, ethnic and political complexity.

\section{Theoretical framework}

As we already mentioned, in the last two decades toponymic studies have undergone a small renaissance within anthropology and geography. This renewed interest in place names was sparked by several influential studies (suffice it to mention TUAN 1991; BASSO 1996; AZARYAHU 1996) which inspired a number of other researchers to investigate the cultural, social, political, and existential dimension of place names in greater detail. While anthropologists have examined principally rural and indigenous communities (e.g. THORNTON 1997a; OLIVEIRA and WAHI 2009), geographers have focused mostly on capital and large cities (e.g. Alderman 2000; Light 2004; Gill 2005; Palonen 2008). As they have differed in the location of their research, so have they used different methods of research - interviewing prevailing in anthropological inquiry and analysis of maps and other official documents helping geographers.

According to the classic cultural geographer Yi-Fu TUAN (1991), place names are not simple arbitrary labels. The relationship between language and place is very intimate. Place names create places, assign them moral value and historical meaning, and transform thus the world into a purposeful and manageable place. The American anthropologist Keith BASSO $(1988,1996)$ takes this argument a step further and explores not only the perceptual but also the existential aspects of toponymy. For him, toponymy bears a profound normative dimension which grounds every person in time and place. For BAsso, place-naming is a key element in everyday place-making whereby we relate to, and create, the world in a poetic, imaginative fashion. The world we live in is a place-world, a world 
of lived moral practice made of places (and place names) as its fundamental building blocks. Place names are anchors of one's identity, providing a sense of home, self and belonging. The Austrian geographer Peter JoRDAN develops this argument in the context of debates over landscape and cultural heritage. If cultural landscapes are worthy of protection and if place names are a part of these landscapes, they too should deserve systematic protection. For JORDAN, place names shape the cultural landscape visibly (signposts) and mentally (by structuring spatial perception), but they also function as symbolic labels in space-related identity building (bilingual signposts) and support emotional ties with place ("feeling at home") (JORDAN 2009, pp. 36-38).

These authors all point out the importance of place names for understanding and establishing our relations with the space we occupy. At the same time, they also acknowledge that the relationship between place names and identities is by no means simple. Toponymic inventories of individuals differ in relation to gender, age, occupation, social status, and other attributes of social differentiation (THORNTON 1997b, p. 221). In addition, place names undergo a constant reinterpretation and transformation and so do the associated identities. Therefore, toponymic inventories and toponymic practice are highly fluid, situational, and dynamic, and thorough ethnographic studies of these phenomena are yet to come in greater numbers (for rare examples of these see e.g. GABBERT 2007; DAVID and Mácha 2014).

However, there is yet another dimension to place names and that is power. We are not, and never have been, in equal positions to name places, individually or collectively. Place names may constitute cultural heritage and may be important for establishing and reproducing social identities but they are also loaded with emotions, alternative interpretations, and contested histories and as such they are not politically innocent. It is precisely this focus on the politics of place-naming that the so-called "critical toponymy" has developed (see e.g. Rose-Redwood, Alderman and Azaryahu 2010). Critical toponymy is a lively current within contemporary place name research that critically examines the relationship between toponymy and power. It analyses ways in which political regimes and movements use place names to claim territories, erase linguistic traces of original populations, gain political legitimity, delegitimise other political forces, naturalise certain versions of history and silence dissent. This is possible because of place names' presumed

"ability to incorporate an official version of history into such spheres of human activity that seems to be entirely devoid of direct political manipulation. This transforms history into a feature of the 'natural order of things' and conceals its contrived character" (AZARYAHU 1997, p. 481).

A number of very interesting case studies have appeared in the last two decades that critically analyse the utilisation of toponymy in (post-)colonial settings (e.g. NASH 1999; Herman 1999), as tool in nation-building (e.g. Cohen and Kliot 1992; Үeоh 1996; AZARYAHU and Golan 2001) or as strategy of legitimising political regimes (e.g. HorsMAN 2006). A particular attention within critical place name studies has been paid to commemorative street names in diverse historical, geographical, and political contexts (e.g. González Faraco and Murphy 1997; Alderman 2000; Light 2004; Gill 2005; PaloNEN 2008). It is precisely commemorative names referring to people, events, and places 
with symbolic significance that are most often (though not exclusively) used by political representatives to express their political orientation and legitimise their political projects. And it is with these names that we are going to be concerned most in this text.

An important concept in the last set of studies is the concept of the city-text (AzARYAHU 1996) which is a useful way to think about the internally heterogenous, palimpsest-like toponymic ensemble of a given city, together with other, non-toponymic and even non-linguistic components which contribute to the expression and reproduction of specific political, territorial, religious, ethnic, national or class identities (e.g. ŠAKAJA and STANIĆ 2011; Bucher et al. 2013).

The symbolic power of place names becomes doubly important in multiethnic/multilingual situations where the questions of cultural heritage, identity, and political representation (in the landscape) become all entangled and contested. As JORDAN (2009) has shown, place names in the landscape in the form of signs and public usage carry symbolic importance for ethnic identity and are a necessary component of minority rights. Place names on public signs also constitute a key component of the linguistic landscape, making the minority both visible and represented but also contributing to the vitality of the minority language (see e.g. CENOZ and GorTer 2006). Indeed, as MARTEN et al. (2012, p. 1) pointed out, "being visible may be as important for minority languages as being heard".

Not always, however, are minority place names on public signs welcome by the majority. Because of conflicting claims over territory, fear of separatism, historical grievances, and other issues, minority, bilingual or multilingual public signs and toponymy may not only represent an opportunity for the minority but also a threat to the majority or other minority/ies living in the area (see e.g. Alderman 2003; Puzey 2009; Azaryahu 2012; SzABó GiLINGER et al. 2012).

To summarise, thanks to the aforementioned research we now see place names in a significantly different light than a few decades ago. Not only do they contain information about the history, character, and inhabitants of a place (which undoubtedly remains an important current of their research), but they also seem to constitute a crucial component in the conceptual, moral, and emotional formation of places and in the individual and collective identity of their inhabitants. At the same time, place names have a political dimension and are strategically used to promote or silence various projects. Large cities - and especially capitals - have been the locus, and the most studied examples, of toponymic politics. While political regime changes typically produce toponymic conflicts, place names become particularly relevant in multilingual and multiethnic situations in which they play a crucial role in the mediation of ethnic relations. When combined with changes of political regimes, changes in ethnic composition, and changes in the position of the place in relation to state borders, place names come out as a powerful and explosive expression of people's need for belonging, order, and control.

\section{Methods}

Even though the aforementioned studies have been insightful, however, they do contain some limitations. The geographical studies much too often focus on large cities (and 
capitals above all) and rely only or predominantly on official documents (namely maps). The anthropological approaches, on the other hand, depend to a large extent on participant observation and interviewing but overemphasise the existential and cultural importance of place names for small, mostly rural and mostly indigenous communities, at the expense of analysing the urban and political dimensions of place names. In our research we therefore chose a mid-way between the two approaches - we studied two small towns and used a mixture of qualitative and quantitative methods. We believe that such a combination is crucial for understanding how place names acquire social meaning beyond their etymologies and how they function to promote national identities and political projects in linguistically and ethnically diverse contexts.

Historical information was principally obtained from Czech and Polish archives. On the basis of old maps a database of all street names of Český Těšín and Cieszyn was compiled, including their spatial location. Several periods were distinguished in the evolution of the toponymic landscape, based on the major political upheavals. These periods are summarised in Table 1 (see chapter 4 for explanation). Street names were categorised on different criteria, following BUCHER et al. (2013). Only some of them are relevant for this article. For the purpose of this text, the analysed criteria were: type of nationalism (Czech, Polish, German, Austrian, Silesian), type of ideology (monarchism, democracy, nazism, clericalism, communism) and level of identification (local, regional, national, international). We followed the frequency and type of renaming in individual periods and compared the two sides of the border.

\begin{tabular}{|l|l|}
\hline Austrian (pre-1920) & Post-War (1945-1948) \\
\hline Interwar (1920-1938) & Communism (1948-1989) \\
\hline Polish (1938-1939) & Democracy (1989 to present) \\
\hline German (1939-1945) & \\
\hline
\end{tabular}

Table 1: Analysed historical periods

While old maps and town plans proved to be useful in many ways, we did not want to depend solely on them (as many authors regrettably continue to do - see e.g. DROZDZEWSKI 2014), so we also studied historic town council meeting minutes, correspondence between different governmental and private institutions and popular petitions, all related to place name changes (or a lack thereof). These other documents provided a rich background for the interpretation of maps and the linguistic landscape visible on old photographs. They also clearly showed that maps are, above all, projects which rarely conform to reality but which very often attempt to make reality conform to them (see e.g. HARLEY 1988).

Information on current toponymic politics was obtained doing sit-in and walking interviews with inhabitants of Český Těšín and Cieszyn, both Czech and Poles, of different age and gender groups. Finally, GIS was used to interpret spatially the database of street names and the transformation of the linguistic landscape. Due to the extensiveness of the GIS-based maps exceeding by far the permitted length of this article, we created a web presentation which the reader is encouraged to open while reading the remaining text. The web address is: http://projekty.osu.cz/tesinsko/mapy/. 


\section{Teschen/Těšín/Cieszyn as a locus of nationalist conflict ${ }^{2)}$}

As we already mentioned, the present towns of Český Těšín, Czechia, and Cieszyn, Poland, originated from a single, mostly German speaking town in Austrian Silesia called Teschen by German speakers. The name "Teschen" is nevertheless derived from a Slavic personal name which testifies to the Slavic origin of the town founder and its inhabitants (LUTTERER and ŠrÁmeK 2004). Teschen/Těšín/Cieszyn was the center of the historic Duchy of Teschen (Ducatus Tessinensis; Herzogtum Teschen), politically controlled by Polish kings and locally administered by the Teschen Piast dynasty. From the early $14^{\text {th }}$ century the Duchy became - together with other Silesian duchies - an integral part of the Czech Kingdom (Království české; Königreich Böhmen) which was gradually incorporated into the Austrian Empire during the 1500s after the Habsburgs took control of the Czech Kingdom. The location of this historic duchy is indicated on Map 1.

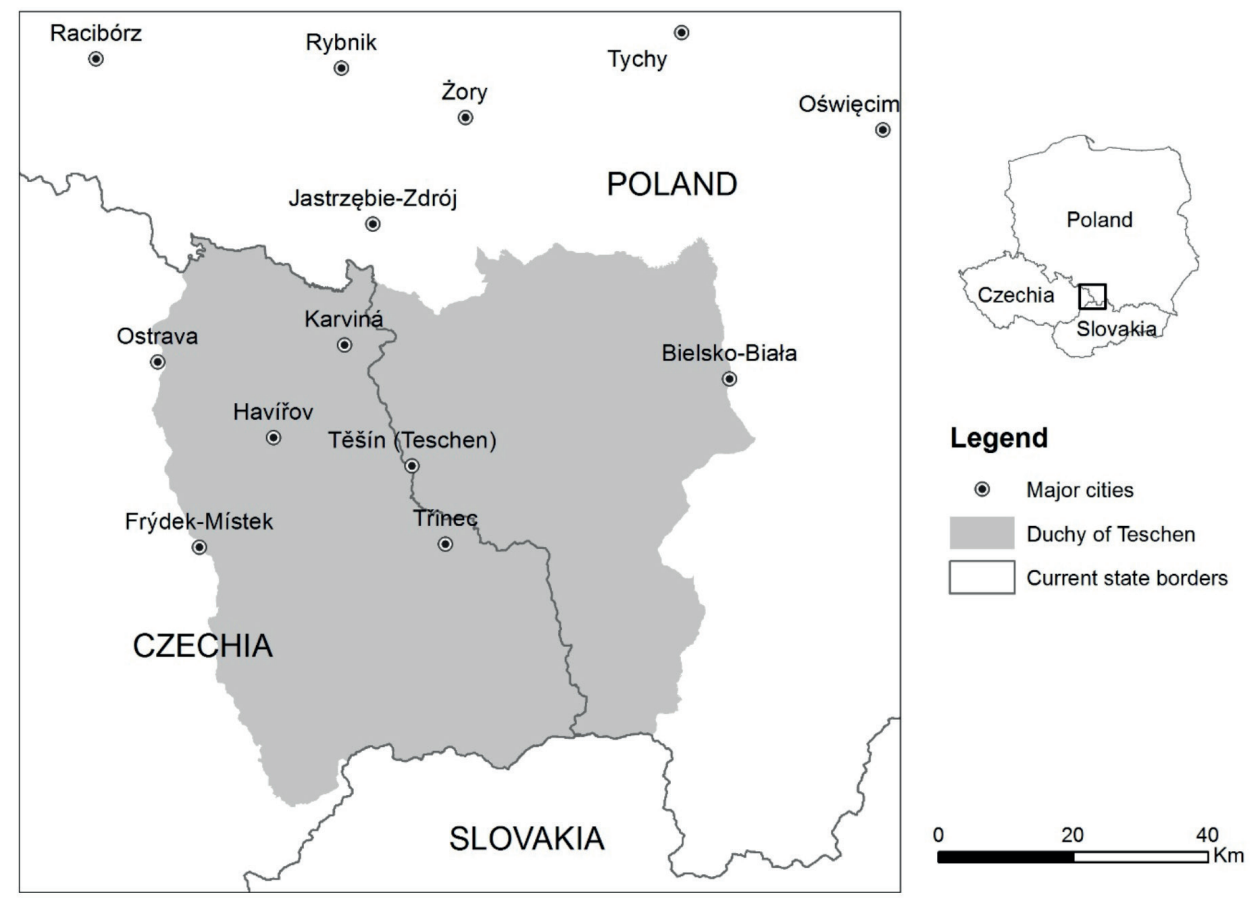

Figure 1: Location of the Teschen Region

\footnotetext{
2) This is not the time and place to give a detailed history of the analysed region. We limit ourselves to basic information, especially such information which had direct influence upon ethnic and toponymic conflicts. For readers with greater interest in Teschen history we recommend e.g. BoRÁK and GAWRECKI (1992) and KADŁUBIEC (1997).
} 
It was during the 1500 s that the duchy became heavily influenced by the Protestant Lutheran movement and a significant portion of the population remained Protestant during the ensuing centuries in spite of the re-Catholisation efforts of the Habsburgs. After the end of the Piast dynasty in the $17^{\text {th }}$ century, the Duchy became the property of the Habsburgs and unlike the majority of Silesia which was lost to the Prussians during the reign of Marie Theresie in the 1740s Teschen remained part of Austria and in the direct possession of the Habsburgs until 1918. The local branch of the Habsburg family was known as Sachsen-Teschen.

It was only after the incorporation of the Czech crown lands into the Habsburg empire and especially after the end of the Piast dynasty that the number of German speakers in the town began to rise rapidly and the German language gradually began to replace Czech as the main language of official communication. With the exception of several villages around Bielsko [Bielitz] (today in Poland), the German speaking population concentrated only in towns - apart from Teschen itself also in Frýdek [Friedek], Bohumín [Oderberg] and Fryštát [Freistadt] (today in Czechia) and Skoczów [Skotschau] and Strumień [Schwarzwasser] (today in Poland). The countryside remained Slavic.

Teschen as a regional administrative center attracted educated Polish, Czech and German elites - teachers, priests, politicians, businessmen, state officials - and during the second half of the $19^{\text {th }}$ century became a locus of nationalist conflict. The battle for the national identity of the entire duchy was fought here. During the $19^{\text {th }}$ century the region also saw increased immigration from Austrian Galicia which especially affected the ethnic composition of the industrialised part of the duchy but also Teschen as its center. According to the last Austrian census carried out in 1910 Teschen had 21,550 permanent inhabitants. Of those, 13,254 (61,5\%) spoke German, 6,832 (31,7 \%) Polish, 1,437 (6,7 \%) Czech and 27 (0,1\%) other languages (PATRYN 1912, pp. 58-59).

At this time, spoken language (Umgangssprache) was used to determine nationality. Austrian statistics later played a crucial role in legitimising ethnic claims over territory. Interestingly, the majority of local Slavic-speakers did not use Czech or Polish but the local language/dialect colloquially referred to as "gwara" or "po našimu" ("in our language"). While Czech linguists considered the dialect "Czech" or "mixed", Austrian (and Polish) linguists classified it as Polish and so the population appeared as Polish in the census (on linguistic issues see Bogoczová 1997). As we shall still see, this was not an unproblematic categorisation.

To make things even more complicated, a special phenomenon formed in the region known as the Silesian (Šlonzak) movement. Šlonzaks were mostly Slavic speakers and identified with the historic Silesia. Due to the predominant German speaking character of Silesia, however, they also identified with this German element and politically sided with it in local and regional elections. This movement strongly influenced local politics up to Worlld War II and a clear testimony to its prominence is the fact that its leader - Josef Koždoň - was the mayor of Český Těšín during the entire interwar period. ${ }^{3)}$

\footnotetext{
3) For information on the demography of the Silesian (Šlonzak) movement during this period see e.g. GAWRECKI 2014.
} 
And finally, in addition to this complex ethnic and linguistic situation, ethnic diversity was cross-cut by religious diversity: $67,3 \%$ of local inhabitants were Catholics, $23 \%$ Protestant and 9,4 \% Jewish (PATRYN 1912, pp. 58-59). A disproportionately high number of Poles were Protestant and so was the majority of Polish nationalist leaders in the region which makes it rather specific in view of the importance of Catholicism in Poland.

In 1918, after the end of World War II, the Teschen region became a point of serious conflict between the newly created states of Czechoslovakia and Poland. While the Czechoslovak government claimed the region on the basis of its historic, political and administrative ties with the Kingdom of Bohemia within the Austrian Empire, the Polish government appealed to the principle of national self-determination and used the Austrian population census to argue that the majority of the local population was in fact Polish. While in Teschen itself, Polish-speakers formed a minority, in the region as a whole they formed the majority (Polish 54,8 \%, Czech 27,1 \% and German $18 \%$ ) (STUDNICKI 2015, p. 89). Presumed Polish speakers concentrated in the north-eastern two thirds of the region while Czech speakers lived principally in the south-western rim (see SIwEK 1996 for details).

The negotiations did not go very well, led to the so-called "Seven Day War" between the Czechoslovak and Polish armies, and resulted in a stalemate. After a failed referendum attempt which did not seem to go very well for the Polish government, a compromise was finally achieved in Paris and in 1920 the Teschen region was officially divided between Poland and Czechoslovakia. A total of 17 settlements were divided by the new state border, including the town of Teschen. With 1920 the Austrian period came to its final end.

The eastern part of Teschen including its historic center and remains of a medieval castle but also including the vast majority of public buildings, schools and public infrastructure became Cieszyn, Poland. The western part of Teschen representing only about one third of the town's inhabitants and buildings which had mostly residential and business character became (Český) Těšín, Czechoslovakia. There was a short conflict over the official name of the Czechoslovak part of the town since the Czechoslovak government hoped for future reunification of the whole region under Czechoslovak rule. The use of Český Těšín instead of just Těšín was seen as an acceptance of the Polish control of the historic part of the town. The moderates, however, prevailed and in 1921 the Czechoslovak part of Teschen was officially named Český Těšín (KRŮL 2011).

The state border was placed in the river bed of the Olza river dividing the two parts of the town. Since the name Olza was seen as "unCzech" by Czechoslovak authorities, the name "Olšs" was promoted as the official name of the river which now appears on all maps, signs and official documents. Etymologically there is no affinity between Olza and Olše and as our interviews showed, most inhabitants of Český Těšín use only Olza regardless of their nationality. Still Olše is seen as an expression of the Czech claim over the territory and all attempts at changing the official name to its original form Olza have been resisted.

The interwar period (1920-1938) was marked by changes in ethnic composition on both sides of the border and fervent construction in Český Těšín as the new town had to build almost all public buildings and infrastructure. Although there was some population exchange leading some Poles living in Český Těšín to move to Cieszyn (and vice versa), 
a far greater impact came with the changes in the methodology of the state census on the Czechoslovak side and immigration to Český Těšín and Cieszyn from the Czechoslovak and Polish interiors. As a result, the original German speaking majority gradually became a minority in both towns, maintaining, nevertheless, a significant demographic, economic, cultural and political presence.

The Czechoslovak census used subjective national identity preference instead of the spoken language to assign nationality. Already the first census in 1921 showed a dramatic decrease in the number of Poles, especially in the countryside, which testifies to the nationally rather ambiguous orientation of local inhabitants and problems associated with the Austrian use of purportedly objective criteria such as language to assign national membership. Overall, we may conclude that the larger Czechoslovak-Polish conflict which led to the creation of two separate border towns transformed into Czech-German (in Český Těšín) and Polish-German (in Cieszyn) conflicts with an additional enemy on the other side of the border. All of this impacted the toponymic politics documented below.

In 1938 Poland took advantage of the weakening of Czechoslovakia after the Munich agreement and the occupation of the Sudeten lands by Germany. Poland invaded the majority of the Czechoslovak part of the historic Teschen duchy, closed down Czech schools and institutions and implemented a strict Polish-only policy which had a strong impact on place names on the former Czechoslovak side. Many Czech inhabitants lost their possessions and approximately 30,000 fled into the interior accompanied by approximately 5,000 Germans (BoRÁK 1992). Even though this period lasted only one year, it has left feelings of historical grievances on the Czech side which continue to affect Czech-Polish relations in the region.

In 1939 the entire region was invaded by Germany and a thorough Germanisation campaign was undertaken, affecting also toponymy and statistical ethnic composition. The German census began to use Silesian (Šlonzak) nationality as one of the accepted national categories and the region saw a dramatic decrease of Poles and Czechs and an equally dramatic increase in Silesians and Germans as a consequence. In the former Polish part of the newly established district of Teschen the 1939 census showed 72,3\% of Silesians, $22,7 \%$ of Poles and 4,6 \% of Germans, in the Czech part of the district it counted 40,4 $\%$ of Silesians, $24,4 \%$ of Czechs, $22,7 \%$ of Poles and $12 \%$ of Germans. In the town of Teschen itself, by 1943 Germans represented $90 \%$ of all inhabitants. The Jewish population disappeared entirely (BORÁK 2011).

After the end of World War II in 1945, the town was once again divided between the reinstated Czechoslovakia and Poland along the pre-war borders. Limited democracies were implemented with some political parties banned and the Communist party growing in strength. With the forced removal of the entire German-speaking population and a political crack-down on Silesian parties the ethnic scene on the Polish side of the border became Polish-only, while there remained a significant Polish minority on the Czech side, relatively small in Teschen itself and reaching up to $50 \%$ in many villages in the region (see e.g. ZAHRADNIK 1992).

By 1948 the dominant role of the Communist parties in both countries was secured and a new period of political and toponymic practice emerged, ending only in 1989. It was 
a period of rapid demographic and urban growth. The Polish minority in Czechoslovakia became well organised under the auspices of the Polish Cultural and Educational Association (PZKO - Polski Związek Kulturalno-Oświatowy) tied to the Communist party. In spite of well-developed Polish schooling and cultural activities, the period saw a steady decline in the number of people identifying with Polish nationality, principally due to assimilation. The period was not marked by major political upheavals which would affect urban toponymy with the exception of the destalinisation process.

Since the end of the communist regimes in 1989, both towns have tried to come to terms with its communist past. Czechoslovakia dissolved into Czechia and Slovakia but this had little impact on Český Těšín. The border crossing between Český Těšín and Cieszyn became a major smuggling point and people from both sides began to shop on the other side of the border in large numbers. After the entry of Poland and Czech Republic into the Schengen space and the dissolution of the border, the towns have gradually searched for a common ground, but this has been very cautious since the memory of historical grievances and fears of unilateral reunification are still alive. In 2007-2008, after a bitter conflict, Český Těšín implemented a system of bilingual Czech-Polish street signs. The number of Poles in Czechia, however, continues to decline. Inhabitants move freely around the two towns, shopping, eating, living, sending their children to school, etc. on the other side of the border. We can conclude that in the lived practice, the towns are being reunited, while in the political and toponymic practice they remain strictly apart.

\section{The politics of toponymy and the urban space}

During the last decades of the first (Austrian) period, Teschen experienced urban growth which affected especially the western (future Czechoslovak) part of the town. The map of the Land Register of Francis I. ("Franziszeischer Kataster") made in 1836 shows the western part of town as a rural area with a few residential farm buildings and roads connecting Teschen with other towns in the region. There was no named urban object. By contrast, the same map shows the eastern (future Polish) part of town as a well defined urban space with the historic center and many named streets and squares. Only a fraction of them were commemorative names, most objects bore names referring to important buildings and institutions (e.g. Convent Gasse) or their own form (e.g. Breite Gasse). By 1872, there still was only one named object on the future Czech side (HAUSER 1872). However, this changed significantly afterwards and by the end of the Austrian period, the western part of town had already many named streets and other urban objects.

The most prominent feature of commemoration in street names during this period were the ruling Habsburg family and important representatives of the monarchy. Examples could include Kaiser Franz Joseph Brücke, Kaiserin Elisabethstrasse and Kronprinz Rudolfsplatz. The local branch of the Habsburg family was also commemorated - examples from the western part of town include a newly built town park named Albrechtsallee and the crucial commercial street named Sachsenberg, both referring to Albrecht von SachsenTeschen. An equally important feature of street naming in this period was the reference to German nationalism, often combined with the commemoration of important local and 
regional figures. As examples we can mention Demelplatz (named after the former German-speaking mayor of Teschen) or Hoheneggerstrasse (named after the manager of industrial operations and the Teschen estate). The importance of local and regional figures in the toponymy of the historic part of Teschen was, as we shall see, to remain a stable feature of local toponymic politics.

We documented a total of 134 names during this period of which $31 \%$ were commemorative. The use of commemorative names was significantly more prominent in the western part of town where new streets and other objects were built whereas in the old part of the town, historic names were often respected. However, even in the historic center several commemorative names replaced original names - e.g. Hauptplatz became Demelplatz and Polnische Gasse became Kronprinzessin Stephaniegasse. This latter case is symbolic for the nationalist conflict over public toponymy in the century to come. Map 2 (online, http:// projekty.osu.cz/tesinsko/mapy) documents the location and ideological characterisation of street name changes during the Austrian period. Tables 2 to 5 document the extent of changes, use of commemorative names, importance of individual ideologies and levels of identification in different periods.

The second - inter-war - period began with the division of Teschen and its transformation from an interior to a border town. In Český Těšín on the Czechoslovak side, first plans for the renaming of public objects appeared already before it was clear which country would control the region. ${ }^{4)}$ The plans were accompanied by heated conflicts between local officials and representatives of the German-speaking population. Czech officials demanded the replacement of German signs and the erasure of all references to the Habsburgs and German nationalism. ${ }^{5)}$ ) Even institutions which we would not expect to enter such discussions in a democratic country became involved - e.g. deputy commander ${ }^{7)}$ and commander of the local military base. ${ }^{8)}$

By contrast, German-speaking inhabitants fought to preserve what they could and they were actively supported by the local Silesians (Šlonzaks). ${ }^{9}{ }^{9}$ These two groups were also more supportive of local Poles and demanded that street signs be trilingual. Czech nationalism was the dominant toponymic feature in this period - streets, parks and squares were mostly named after nationally celebrated artists, politicians and institutions with few or no ties to the region - e.g. nám. Dr. Beneše (Dr. Beneš Square, after the minister of foreign affairs Edvard Beneš) or Masarykovy sady (Masaryk Park, after the Czechoslovak president Tomáš G. Masaryk). Thereby the Czech and Czechoslovak identity of the

4) SOkA Karviná, f. AM Český Těšín (1416) 1920-1945, č. listu NAD 234, kart. 27, inv. č. 103. Protokol podkomité o změně pojmenování ulic z 16. března 1920.

5) SOkA Karviná, f. AM Český Těšín (1416) 1920-1945, č. listu NAD 234, kart. 27, inv. č. 103. Výpis ze zasedacího protokolu z 26. dubna 1921.

6) SOkA Karviná, f. AM Český Těšín (1416) 1920-1945, č. listu NAD 234, kart. 27, inv. č. 103. Spis 1344 a.

7) SOkA Karviná, f. AM Český Těšín (1416) 1920-1945, č. listu NAD 234, kart. 27, inv. č. 103. Major Pilař. 16. března 1921.

8) SOkA Karviná, f. AM Český Těšín (1416) 1920-1945, č. listu NAD 234, kart. 27, inv. č. 103. Č.j. 162/dův major Hrůza 18. června 1921 - Německých tabulek odstranění.

9) SOkA Karviná, f. AM Český Těšín (1416) 1920-1945, č. listu NAD 234, kart. 27, inv. č. 103. Č.j. 1344/2 z 18. července 1921. 


\begin{tabular}{|l|c|c|}
\hline \multicolumn{1}{|c|}{ Period } & Český Těśńn & Cieszyn \\
\hline Austrian & \multicolumn{2}{|c|}{$8 \%$} \\
\hline Inter-war & $24 \%$ & $26 \%$ \\
\hline Polish & $80 \%$ & $8 \%$ \\
\hline German & $87 \%$ & $68 \%$ \\
\hline Post-war & $79 \%$ & $71 \%$ \\
\hline Communism & $10 \%$ & $5 \%$ \\
\hline Democracy & $8 \%$ & $7 \%$ \\
\hline
\end{tabular}

Table 2: Extent of name changes (renamed streets as percent of all streets)

\begin{tabular}{|l|c|c|}
\hline \multicolumn{1}{|c|}{ Period } & Český Těš́n & Cieszyn \\
\hline Austrian & \multicolumn{2}{|c|}{$31 \%$} \\
\hline Inter-war & $38 \%$ & $47 \%$ \\
\hline Polish & $82 \%$ & $48 \%$ \\
\hline German & $54 \%$ & $34 \%$ \\
\hline Post-war & $36 \%$ & $50 \%$ \\
\hline Communism & $26 \%$ & $38 \%$ \\
\hline Democracy & $21 \%$ & $35 \%$ \\
\hline
\end{tabular}

Table 3: Commemorative names (percent of all names)

\begin{tabular}{|c|c|c|}
\hline Period & Český Těšín & Cieszyn \\
\hline Austrian & \multicolumn{2}{|c|}{ monarchism $(46 \%)$, German nationalism $(41 \%)$} \\
\hline Inter-war & $\begin{array}{c}\text { Czech nationalism (52 \%) } \\
\text { German nationalism (35\%) }\end{array}$ & $\begin{array}{l}\text { Polish nationalism (79\%) } \\
\text { German nationalism (13\%) }\end{array}$ \\
\hline Polish & $\begin{array}{c}\text { Polish nationalism }(98 \%) \\
\text { Christianity }(2 \%)\end{array}$ & $\begin{array}{c}\text { Polish nationalism }(93 \%) \\
\text { Christianity }(6 \%)\end{array}$ \\
\hline German & $\begin{array}{c}\text { German nationalism }(75 \%) \\
\text { Nazism }(25 \%)\end{array}$ & $\begin{array}{c}\text { German nationalism }(81 \%) \\
\text { Nazism }(19 \%)\end{array}$ \\
\hline Post-war & $\begin{array}{l}\text { Czech nationalism }(80 \%) \\
\text { Communism }(12 \%)\end{array}$ & $\begin{array}{c}\text { Polish nationalism }(88 \%) \\
\text { Christianity }(8 \%)\end{array}$ \\
\hline Communism & $\begin{array}{l}\text { Czech nationalism }(61 \%) \\
\text { Communism }(32 \%)\end{array}$ & $\begin{array}{l}\text { Polish nationalism }(78 \%) \\
\text { Communism }(18 \%)\end{array}$ \\
\hline Democracy & $\begin{array}{l}\text { Czech nationalism (88 \%) } \\
\text { Polish nationalism }(6 \%)\end{array}$ & $\begin{array}{l}\text { Polish nationalism (95 \%) } \\
\text { Christianity }(5 \%)\end{array}$ \\
\hline
\end{tabular}

Table 4: Dominant ideology (percent of all ideologically motivated names)

\begin{tabular}{|l|c|c|}
\hline \multicolumn{1}{|c|}{ Period } & Český Těšín & Cieszyn \\
\hline Austrian & \multicolumn{2}{|c|}{$18 \%$} \\
\hline Inter-war & $33 \%$ & $47 \%$ \\
\hline Polish & $20 \%$ & $29 \%$ \\
\hline German & $20 \%$ & $20 \%$ \\
\hline Post-war & $13 \%$ & $36 \%$ \\
\hline Communism & $7 \%$ & $25 \%$ \\
\hline Democracy & $7 \%$ & $33 \%$ \\
\hline
\end{tabular}

Table 5: Regional level of identification (percent of names expressing identity) 
local population was to be promoted. The Habsburgs were the main target of renaming. However, local Germans resisted this fiercely, managed to negotiate the preservation of several German and even Habsburg names (most visibly Sachsenberg) and prevented the renaming of a street after Woodrow Wilson. Poles were not given any public recognition in street names.

Český Těšín experienced a dramatic growth and many new objects had to be named. A total of 63 names were documented for Český Těšín in this period, of which 24, i.e. 38 $\%$ were commemorative. With a few exceptions - e.g. Hinterstoisserova (Hinterstoisser Street after the local German-speaking hospital director ${ }^{10)}$ ) or Čapkova (Čapek Street after the local legionair Jan Čapek), most toponymic references were to national figures. There was a total of 15 name changes during this period, affecting $24 \%$ of all streets.

In Cieszyn on the Polish side, the inter-war period ran many parallels but also important differences in comparison with Český Těšín. Discussions about renaming also began there before it was clear to which country the region would belong. ${ }^{11)}$ However, unlike in Český Těšín, local Poles and Germans established a joint commission which made decisions on street name changes. In spite of initial good will, though, finding a consensus was not always possible, especially in cases when changes were seen by either side as a threat to their national identity. ${ }^{12)}$

As in the case of Český Těšín, the main targets of renaming were names associated with the Habsburgs. Compromise deals were struck in which each party achieved partial victory. For example, Demelplatz, the main square, was renamed to Rynek (main square in Polish cities) but a side street was newly named after Demel (Demla) while Prutka (Prutek Street) kept its name in spite of Polish protests (Jerzy Prutek was a $19^{\text {th }}$ century excommunicated Catholic priest who played an important role in the development of Teschen but sided with German and Silesian currents in local politics, therefore was seen as a traitor to the Polish cause). Debates also emerged about street signs which were only in German, making it - in the words of one Polish town council member - difficult for Poles to find their way around their town. ${ }^{13)}$

The dominant ideological message of urban toponymy was Polish nationalism. For example, Gtęboka (Deep Street) was renamed to Legionów (Legion's Street) in recognition of the role of Silesians in the creation of the so-called Second Polish Republic. ${ }^{14)}$ Interestingly, it was also the Czechoslovak legions that played the decisive role in the aforementioned "Seven Days War" over the Teschen region in 1919. We could therefore consider this name a cross-border message. Evangelical clericalism played a role in the adaptation

10) SOkA Karviná, f. AM Český Těšín (1416) 1920-1945, č. listu NAD 234, kart. 27, inv. č. 103. Výpis z protokolu 28. plenárního schůze městského zastupitelstva v Českém Těšíně 7. listopadu 1930.

11) Archiwum Państwowe w Katowicach Oddział w Cieszynie. F. 14/3. Syg. 61: Protokoł z posiedzeń Komisji Administracyjnej miasta Cieszyna. Těšín. 7.12.1920, s.5.

${ }^{12)}$ Archiwum Państwowe w Katowicach Oddział w Cieszynie. F. 14/3. Syg. 61: Protokoł z posiedzeń Komisji Administracyjnej miasta Cieszyna. Těšín. 7.12.1920, s.5.

13) Archiwum Państwowe w Katowicach Oddział w Cieszynie. F. 14/3. Syg. 61: Protokoł z posiedzeń Komisji Administracyjnej miasta Cieszyna. Těšín. 7.12.1920.

14) Archiwum Państwowe w Katowicach Oddział w Cieszynie. F. 14/3. Syg. 76: Protokoł z posiedzeń Rady Gminnej miasta Cieszyna.Těšín. 10. října 1934. 
of street names referring to evangelical priests Heczko and Haas by preceding their names with the title "priest". ${ }^{15)}$ It was a symbolic victory after the long centuries of Catholic domination. Overall, during the inter-war period we documented 128 official names for Cieszyn, of which 60, i.e. $47 \%$ were commemorative. Renaming affected approximately $26 \%$ of all streets. Interestingly, the regional level of identification became the most important in this period. Cieszyn was thus emphasising its role as the guardian of local and regional memory and the legitimacy of its historic claim to the entire region. In all other periods on both sides of the border the national level prevailed. See Map 3 (online, http:// projekty.osu.cz/tesinsko/mapy) for details.

The Polish period in Český Těšín lasted barely a year (1938-1939) but was the most influential, relatively speaking. After the Polish army invaded Český Těšín in October 1938, the town was reunited with Cieszyn. Shortly afterwards the entire urban toponymy of former Český Těšín was reinscribed. All names alluding to the presence of Czechs (and Germans) and the existence of Czechoslovakia were replaced by names celebrating Polish history and representatives of Poland. For example, Sachsenberg became Pitsudskiego (Józef Piłsudski was Polish prime minister) and nám. Dr. Beneše was renamed to plac Becka (Józef Beck was Polish minister of foreign affairs and a close associate of Piłsudski). This renaming affected, however, also originally neutral, non-commemorative names and the entire city text was politicised. One of the few streets that survived this revolution was Tranovského/Trzanowski named after the influential $17^{\text {th }}$ century evangelical priest Jiří Třanovský (Jerzy Trzanowski), anachronically reinterpreted by the Polish government as Polish (KAMUSELla 2007, pp. 88-89).

A second wave of renaming occurred in the spring of 1939 when streets in the eastern part of town were renamed. German names were the targets of this campaign and the changes were implemented quickly. ${ }^{16)}$ It was a unilateral decision of the Polish representatives, German representatives protested and then left the town council meeting. ${ }^{17)}$ As a result, German street names disappeared from the city text, be it for their renaming or for their formal merging with streets bearing Polish names. Overall, Polish nationalism was by far the dominant motivation for name changes. We documented a total of 181 names for this period, of which 109, i.e. $60 \%$ were commemorative. Of the 62 name changes, 52 occurred in former Český Těšín. Staggering $80 \%$ of streets in former Český Těšín were renamed while only $8 \%$ in Cieszyn. Commemoration also became the dominant feature in name selection in former Český Těšín - of 65 documented names, 53, i.e. 82 \%, were commemorative, referring to Polish national heroes in their majority. As a result, ironically, former Český Těšín was toponymically more Polish than Cieszyn - Polish nationalism accounted for $98 \%$ of all ideologically motivated names in Český Těšín as compared to 93 $\%$ in Cieszyn. See Map 4 (online, http://projekty.osu.cz/tesinsko/mapy) for details.

\footnotetext{
${ }^{15)}$ Archiwum Państwowe w Katowicach Oddział w Cieszynie. F. 14/3. Syg. 78: Protokoł z posiedzeń Rady Gminnej miasta Cieszyna. Těšín. 29. dubna 1938.

16) Archiwum Państwowe w Katowicach Oddział w Cieszynie. F. 14/3. Syg. 79: Protokoł z posiedzeń Rady Gminnej miasta Cieszyna z 17. dubna 1939. Těšín.

17) Archiwum Państwowe w Katowicach Oddział w Cieszynie. F. 14/3. Syg. 79: Protokoł z posiedzeń Rady Gminnej miasta Cieszyna ze 7. června 1939. Těšín.
} 
On September 1, 1939, the Teschen region was invaded by the German army. Name changes were implemented very quickly. Earliest found archival documents (from October 1939) indicate a committee on name changes had been already established. ${ }^{18)}$ This committee prepared a proposal suggesting the renaming of streets after top representatives of the Nazi regime. ${ }^{19)}$ Because higher authorities pointed out that public spaces could not be named after individuals who were still alive (with the exception of Adolf Hitler), this proposal had to be adapted. ${ }^{20)}$ Different local institutions participated in this discussion e.g. the evangelical congregation proposed the renaming of the space in front of the evangelical church in the western part of town after Martin Luther. After ideological review of this proposal, it was accepted, even though the Nazi authorities were not very supportive of churches. ${ }^{21)}$

The renaming took place on December 5, 1939. In addition to the elimination of all Polish names the town itself was once again renamed to Teschen. ${ }^{22}$ In violation of the "dead person only rule", the main square in former Český Těšín was renamed after Hermann Göring (Hermann-Göring-Platz). Other streets and public spaces were named after various historic German figures or returned to their older names from the Austrian period.

German authorities were very meticulous in erasing all details which might remind of the existence of previous institutions. For example, they renamed the streets Bóznicza referring to the presence of a Jewish synagogue, burned down by the Nazis, or the street Gymnazijni referring to the originally Czech (and Polish during the Polish period) high school closed down by the Nazis and turned into a dormitory for refugees. Not all commemorative names were changed, however. In some cases, the Nazi authorities used the same strategy as the Polish authorities in relation to the aforementioned Tranovský street - they reinterpreted historical figures as Silesians and Germans in order to justify historic German presence in the region and sway the nationally ambiguous population in favor of the Germanising project. So, for example, streets called Piastowska (after the royal dynasty), Szersznika (after Leopold Szersznik, local Polish jezuit and a central cultural figure) and Kopernika (after Nicolaus Copernicus) kept their names even though these were previously strongly associated with Polish nationalism.

Interestingly, archival documents indicate that older, ideologically unacceptable names remained in everyday use and German authorities had to repeatedly reprimand state and private institutions, clubs, civic associations and companies and urge them to use the new names only. The effort of German authorities even exceeded state borders when

18) SOkA Karviná, f. AM Český Těšín (1416) 1920-1945, č. listu NAD 234, inv. č. 235, yg.001/103. Dopis starosty Koperberga z 20. října 1939. Těšín.

19) SOkA Karviná, f. AM Český Těšín (1416) 1920-1945, č. listu NAD 234, inv. č. 235, syg.001/103. Př́loha k dopisu starosty Koperberga z 20. října 1939. Těšín.

20) SOkA Karviná, f. AM Český Těšín (1416) 1920-1945, č. listu NAD 234, inv. č. 235, syg.001/103. Dopis Dr. Krügera těšínskému landrátovi z 27. října 1939. Katowice.

21) SOkA Karviná, f. AM Český Těšín (1416) 1920-1945, č. listu NAD 234, inv. č. 235, syg.001/103. Dopis těšínského evangelického společenství pro starostu Koperberga ze 16. listopadu 1939. Těšín.

${ }^{22)}$ SOkA Karviná, f. AM Český Těšín (1416) 1920-1945, č. listu NAD 234, inv. č. 235, syg.001/103 Obsílka starosty Těšína lokálním úřadům a institucím z 20. prosince 1939. Těšín. 
the Teschen mayor discovered on one of his official visits to Slovakia that the older name of the town still appeared on postcards distributed in Slovakia and contacted the German ambassador in Bratislava and the director of the German railways with requests for correction. Although he did not succeed, he continued with his requests. As late as November 1944 when the prospects of Germany were not exactly good, he reprimanded a local company $^{23)}$ and a store ${ }^{24)}$ for using old names.

During the German period, names returned to many previous German names of non-commemorative character which resulted in a general decrease in the use of commmemorative names - from $60 \%$ during the Polish period to $42 \%$ for the entire town. Commemoration, however, remained more dominant in former Český Těšín where there often were no non-commemorative names to return to. Renaming was also much more intensive in former Český Těšín, due to the previous ideologisation of the city text during the Polish occupation. Interestingly, all of the previously renamed streets (85) were renamed again, accounting for $60 \%$ of all renamed streets. German nationalism and nazism were the principal motivating factors for name selection. It is also important to point out that the regional level of identification expressed in street names achieved the lowest score of all periods. Clearly, the strategy was to incorporate Teschen into the German state toponymically and weaken emotional ties to the region. See Map 5 (online, http://projekty. osu.cz/tesinsko/mapy) for details.

The liberation of the town by the Red Army in May 1945 brought about a brief period of democratic reconstruction before the ascent of communism. Czechoslovakia and Poland were reestablished and Teschen was once again divided into Český Těšín and Cieszyn. Toponymy mostly returned to pre-war times, in the case of Český Těšín before the Polish period. By the end of May 1945, most pre-war street names were reinstated.

Significant changes, however, affected German names. In view of the expulsion of the German population and extremely strong anti-German sentiments, any reminders of, or associations with, Germany and Germans, regardless of their non-ideological character, were eliminated. Hermann-Göring-Platz became Nám. Dr. Beně̌e again while Dr. Hintostoisser, Illich and Sachsenberg streets disappeared. As archival materials indicate, overseeing authorities paid a great attention to this question. ${ }^{25)}$

As an expression of gratitude for the war effort, names honoring the Soviet Union began to appear, promoted especially by the local branch of the Communist Party. Prominent streets in Český Těšín were named after Moscow (Moskevská), Red Army (Rudé armády) and Stalin (Stalinova). In the last case, it had to be approved by the national interior ministry and a petition accompanied by photographs of the public space to be named after Sta-

23) SOkA Karviná, f. AM Český Těšín (1416) 1920-1945, č. listu NAD 234, inv. č. 235, syg.001/103 Dopis těšínského starosty strojírenskému závodu Kisling \& Skrobanek ve věci firemního loga a razítka z 11. ř́jna 1944. Těšín.

24) SOkA Karviná, f. AM Český Těšín (1416) 1920-1945, č. listu NAD 234, inv. č. 235, syg.001/103 Dopis těšínského starosty velkoobchodu Mathias Dymny z 2. listopadu 1944.

25) SOkA Karviná, f. Okresní národní výbor Český Těšín, dodatky 1945-1948 (1950), č. listu NAD 179, kart. 58, inv, č. 33, syg. II. Oběžník ministerstva vnitra o odstranění nevhodných názvů veřejných míst z 10. srpna 1945. Praha. 
lin had to be sent to Moscow. ${ }^{26)}$ The Communist Party, however, promoted ideologically motivated names, as well. As a result, Marxova (Marx Street) was reinstated and Střelecká was renamed to Švermova (after Jan Šverma, a communist journalist and politician). ${ }^{27)}$ Overall, we documented a total of 75 names in this period, of which 27, i.e. $36 \%$ were commemorative. 59 streets (79\%) were renamed. Of the 59 names changes, 49 (83\%) affected the previously renamed streets. As can be expected, the predominant ideology was Czech nationalism, referring to Czech national figures in their majority. However, second in importance was communism which shows that the road to the communist victory in 1948 was already paved shortly after World War II.

In Cieszyn, the situation was rather similar. Pre-war names were reinstated with the exception of names associated with the German population. The renaming process was also overseen by higher authorities and was accompanied by heated debates. ${ }^{28)}$ As in Český Těšín, also Cieszyn commemorated Stalin and the Red Army in the urban toponymy - e.g. the main square became Plac Stalina. Other proposed changes, however, did not meet with success. For example, the commemoration of the local anti-Nazi resistance figures proposed by the local security office were not accepted. ${ }^{29)}$ The main tensions could be found between the local communists and representatives of other parties which consistently blocked communist proposals. ${ }^{30)}$ Although a toponymic committee was established, before 1948 no further changes occurred. ${ }^{31)}$ Overall, commemoration remained a crucial tool for the expression of Polish nationalism, accounting for $50 \%$ of all names documented in this period. Unlike in Český Těšín, however, second in importance came Christianity and not communism, suggesting a stronger role of the church in Polish society which continues to the present. The extent of renaming was comparable to Český Těšín. A total of 77 (71 \%) streets were renamed including 74 of the 75 previously renamed streets. The return to pre-war names also led to a greater prominence of regional identity than on the Czechoslovak side, confirming thus the self-understanding of Cieszyn's inhabitants as the guardians of the historic memory of the Teschen region. See Map 6 (online, http://projekty.osu.cz/tesinsko/mapy) for details.

In 1948 both countries saw a definite victory of the communists. On both sides, communism became the dominant ideology in street naming, especially in the first years of the existence of the communist regimes, becoming less prominent towards the end of the

26) SOkA Karviná, f. Okresní národní výbor Český Těšín, dodatky 1945-1948 (1950), č. listu NAD 179, kart. 58, inv, č. 33, syg. II. Zpráva moravskoslezského zemského výboru o pojmenování veř. prostranství jménem cizích státníků z 28. května 1947. Ostrava.

27) SOkA Karviná, f. Okresní národní výbor Český Těšín, dodatky 1945-1948 (1950), č. listu NAD 179, kart. 58, inv, č. 33, syg. II. Zpráva MNV v Českém Těšíně o přejmenování ulice Střelecké na ul. Jana Švermy z 28.11. 1945. Český Těšín.

${ }^{28)}$ Archiwum Państwowe w Katowicach Oddział w Cieszynie. F. 14/229. Syg. 1 Protokol ze zasedání městské národní rady města Těšín z 5. dubna 1946. Těšín.

${ }^{29)}$ Archiwum Państwowe w Katowicach Oddział w Cieszynie. F. 14/229. Syg. 1 Protokol ze zasedání městské národní rady města Těšín z 17. září 1946. Těšín.

30) Archiwum Państwowe w Katowicach Oddział w Cieszynie. F. 14/229. Syg. 1 Protokol ze zasedání městské národní rady města Těšín z 14. dubna 1947. Těšín.

31) Archiwum Państwowe w Katowicach Oddział w Cieszynie. F. 14/229. Syg. 1 Protokol ze zasedání městské národní rady města Těšín 29. května 1947. Těšín. 
period in 1989. In Český Těšín, name changes began to be discussed only in 1949 when a proposal emerged for the renaming of Nádražní (Railway Station Street) to Gottwaldova (after the current president of Czechoslovakia and leader of the Communist Party Klement Gottwald). ${ }^{32}$ After a thorough evaluation of the street's urban importance and visual quality, the proposal was approved. ${ }^{33)}$ This change corresponded well with similar proposals elsewhere and because of their number the Office of the President produced strict criteria for future renaming in the president's name (e.g. only very important objects which did not already bear names of well-known national figures could be named after him) ${ }^{34)}$ However, within a few years the official ideological interpretation of many of these "well-known national figures" changed dramatically (e.g. the first Czechoslovak president Tomáš G. Masaryk, the second president Edvard Beneš, etc.) and by 1953 these figures were described as discredited, bourgeois and enemies of the working class. ${ }^{35}$ Hence, Nám. Dr. Beneše (Dr. Beneš Square) became Nám. Československé armády (Czechoslovak Army Square) while Masarykovy sady (Masaryk's Park) became Gorkého sady (Gorkij's Park, after the Russian writer and revolutionary Maxim Gorkij).

The communist regime attempted to erase all toponymic traces of previous regimes but preferred to do it gradually to maintain a semblance of a continuous, non-violent development. Changes did not occur in waves but convenient anniversaries were used to implement them. ${ }^{36)}$ This was true for the already mentioned renaming of Dr. Beneš Square $^{37)}$ or the naming of a street after the Bulgarian communist leader Dimitrov in the year of his death. ${ }^{38)}$

By 1960, other names legitimising the communist regime appeared - Leninova, Fučikova (after the communist journalist Julius Fučík), Dukelská (referring to Dukla in Slovakia, a Worls War II battle place glorified in the communist ideology) or Kpt. Jaroše (after Otakar Jaroš, a Czechoslovak army officer fighting together with the Red Army). Interestingly, security concerns also affected toponymic changes after the ministry of interior ordered the renaming of all streets bearing names which referred to important objects such as water towers, factories, state offices, etc. ${ }^{39)}$

32) SOkA Karviná, f. Okresní národní výbor Český Těšín 1949-1960 (1964), č. listu NAD 179, inv. č. 281, syg. 0451 Žádost o technický posudek pro přejmenování ulice Nádražní na ul. K. Gottwalda z 26.4.1949. Český Těšín.

33) SOkA Karviná, f. Okresní národní výbor Český Těšín 1949-1960 (1964), č. listu NAD 179, inv. č. 281, syg. 0451 Technický posudek o ulici Nádražní vypracovaný Ing. Z. Lamešem z 11. května 1949. Český Těšín.

${ }^{34)}$ SOkA Karviná, f. Okresní národní výbor Český Těšín 1949-1960 (1964), č. listu NAD 179, inv. č. 281, syg. 0451 Instrukce k pojmenování ulic jménem K. Gottwalda, podepsán Dr. Pavlinec, z 6. září 1950. Český Těšín.

${ }^{35)}$ SOkA Karviná, f. Okresní národní výbor Český Těšín 1949-1960 (1964), č. listu NAD 179, inv. č. 281, syg. 0451. Směrnice MNV Č. Těšín pro přejmenování závodů, budov, škol... z 23. července 1953. Český Těšín.

36) SOkA Karviná, f. Okresní národní výbor Český Těšín 1949-1960 (1964), č. listu NAD 179, inv. č. 281, syg. 0451. Směrnice MNV Č. Těšín pro přejmenování závodů, budov, škol... z 23. července 1953. Český Těšín.

37) SOkA Karviná, f. Městský národní výbor Český Těšín (1964), Kronika města Český Těšín č. listu NAD 235, pořadové č. 152., s. 159.

38) SOkA Karviná, f. Okresní národní výbor Český Těšín 1949-1960 (1964), č. listu NAD 179, inv. č. 281, syg. 0451. Dopis ONV podřízeným úřadům ve věci pojmenování veř. prostranství jménem Dimitrova z 23.7. 1953. Český Těšín.

39) SOkA Karviná, f. Okresní národní výbor Český Těšín 1949-1960 (1964), č. listu NAD 179, inv. č. 281, syg. 0451. Zpráva ministerstva vnitra místním úřadům o přejmenování ulic z 8. července 1949. Praha. 
During the 1960s the communist regime became less repressive and violent and ideological motivations began to play a smaller role in place naming. Český Těšín grew substantially in size during this period but the majority of new names had non-commemorative, non-ideological character. As a result, of the 156 documented names for this period, only 40, i.e. $26 \%$ were commemorative. This is a sharp drop in comparison with the previous periods and the second lowest score in the history of Těšín. The extent of renaming was also drastically lower - only 15 streets $(10 \%)$ were renamed, all of them renamed previously. This comes as a surprise since the communist regime is generally seen as the most ideologically oriented. As it appears, the renaming during the brief post-war period ideologically suited the communist regime. The prevalent ideology of the period was Czech nationalism, followed by communism. The presence of the Polish minority was recognised in three names alluding to Polish national figures (e.g. Park Sikory after Adam Sikora, a local Polish nationalist and benefactor). However, the national level of identification demonstrating the belonging of Český Těšín to Czechoslovakia remained dominant.

The communist period in Cieszyn manifested many similarities. Starting in 1949 there were increased efforts at the elimination of names which referred to the pre-war period or Christianity. At the beginning, however, the new regime was not very successful because of local resistence. ${ }^{40)}$ For some time, the Cieszyn street scape therefore preserved many ideologically undesirable names, and toponymic changes were gradual. For example, representatives of the local chocolate factory proposed the renaming of Blogocka (referring to the village of Błogocice) to Rokossowskiego (after Konstanty Rokossowski, Soviet and Polish Marshal). ${ }^{41)}$

Over time, the communist regime managed to eliminate at least the most ideologically problematic names. Streets with Christian or pre-war allusions such as Hallera (after Józef Haller, Polish general and World War I legionaire), 3-maja (referring to the declaration of the Constitution on May 3, 1761) and Paderewskiego (after Ignacy Jan Paderewski, Polish politician) ${ }^{42}$ were replaced with names alluding to communism such as Waryńskiego (after Ludwig Waryński, Polish socialist), 1-maja (International workers's day) or Nowotki (after Marceli Nowotko, Polish communist). Toponymic changes continued during the 1950s, emphasising the communist ideology - e.g. Sawickiej (after a communist activist), Marchlewskiego (after Julian Marchlewski, Polish communist), 22 lipca (July 22, Polish National Day celebrated by the communist regime), Gwardii Ludowej (People's Guard, a left-wing underground anti-Nazi resistence) or Wieczorka (Polish communist active in Silesia). ${ }^{43)}$ The strategy of reinterpreting names and events continued when the thousandth

\footnotetext{
40) Archiwum Państwowe w Katowicach Oddział w Cieszynie. Zarząd Miejski i Miejska Rada Narodow w Cieszynie 1945-1950 F. 14/229. Syg. 3. Protokol ze zasedání prezidia městská rady z 25. listopadu 1949. Těšín. Prezydium MRN w Cieszynie.

41) Archiwum Państwowe w Katowicach Oddział w Cieszynie. Zarząd Miejski i Miejska Rada Narodow w Cieszynie 1945-1950 F. 14/229. Syg. 3. Protokol ze zasedání prezidia městská rady z 3. listopadu 1949. Těšín.

42) Archiwum Państwowe w Katowicach Oddział w Cieszynie. Prezydium Miejskiej Rady Narodowej v Cieszynie 1950-1973 F. 14/208. Syg. 4. Vyhláška Nr. II/9/54 z 24.4. 1954. Těšín.

43) Archiwum Państwowe w Katowicach Oddział w Cieszynie. Prezydium Miejskiej Rady Narodowej v Cieszynie 1950-1973 F. 14/208. Syg. 9.Vyhláška Nr.VII/24 z 18.11. 1959. Těšín.
} 
anniversary of the acceptance of Christianity was reinterpreted as the anniversary of Polish statehood made visible in the street name Tysiaclecia.

As in Czechoslovakia, the 1960s in Poland saw an ideological thawing which led to a decreased use of ideologically motivated names. At the same time the town grew quickly, both physically as well as administratively, incorporating previously independent villages. With some exceptions (e.g. Waniołki after Franciszek Waniołka, Polish communist and politician) new streets were named using mostly non-commemorative and non-ideologically motivated names. Overall, we documented 263 names in this period, of which 100 , i.e. $38 \%$ were commemorative. The extent of renaming was even lower than in Český Těšín - only 13 streets (5\%) were renamed, all of them previously renamed. As can be expected, Polish nationalism and communism were the two most important ideologies, Christianity coming as third with a total of four names. As in the previous periods, the regional level of identification remained rather important in comparison with Český Těšín. See Maps 7 and 8 (online, http://projekty.osu.cz/tesinsko/mapy) for details. While Map 7 shows the detail of the towns' centres, Map 8 shows the entire townscape documenting the central location of the ideological battles in the larger spatial context.

What remains to be determined more precisely is the question of the renaming of public spaces referring to Stalin after Stalin's death and the end of his personality cult. In both towns, this was an embarassing issue, so the change took place without publicity and no archival records which would make it possible to date the change were found. What we do know is that the street that verifiably bore the name of Stalin still in 1959 is mentioned in the town chronicle of Český Těšín in 1963 as Revoluční (i.e. Revolutionary) without any further explanation. ${ }^{44)}$ In Cieszyn not even such sparse information was found and we only know that in 1977 the main square was once again called Rynek.

1989 brought yet another regime change which also influenced urban toponymy on both sides of the border. In Český Těšín, by 1993 most names referring to communism such as Lenina, Gottwalda, Gorkého, Rudé armády, etc. disappeared. Even the pre-World War II name Marxova was replaced with Divadelni (Theater Street). These streets usually reverted back to their earlier names. The democratic regime, however, was not very consistent and less important urban objects were left unchanged as were those names which referred to less prominent communist figures or which could be ideologically reinterpreted - e.g. Moskevská (newly simply referring to a capital of a country), Nábřeži Míru (Embankment of Peace; who would not want peace?), Pionýrü (Pioneers referring to the communist youth association) or Kpt. Jaroše. The main square remained Československé armády (Czechoslovak army) and it still is even though Czechoslovakia no longer exists. While there was public support for the elimination of the most blatant references to the communist regime in the central part of the town, attempts at renaming all streets referring to communism were often met with popular resistance because people simply wanted to avoid the bureaucratic hassle associated with changing ID cards, driving licenses, passports, etc.

\footnotetext{
44) SOkA Karviná, f. Městský národní výbor Český Těšín (1964), Kronika města Český Těšín č. listu NAD 235, pořadové č. 153. Kronika Českého Těšína pro léta 1963-1974, rok 1963. Český Těšín.
} 
In the following years, newly coined names were only non-commemorative and non-ideological. The only recent attempt at a commemorative name appeared in 2011 to honor the deceased former Czechoslovak and Czech president Václav Havel but this proposal has yet to be realised. As a consequence, commemorative names only represent $21 \%$ of all names in current Český Těšín which is the lowest score of all periods on both sides of the border. In these names, we find primarily Czech nationalism followed (by a wide margin) by Polish nationalism. Overall, only $8 \%$ of streets were renamed. The prominence of the national level of identification has grown further and is the highest of all periods on both sides of the border. This indicates a clear toponymic resignation on the historic claim to the Teschen region.

In Cieszyn (and elsewhere in Poland) the democratic regime has been much more consistent and active in eliminating communist names and this process still continues. Not a single communist name survived this renaming policy. Streets usually returned to their earlier, pre-World War II names. In some cases, new commemorative names were coined - e.g. Sawickiej was renamed to Legionu Ślaskiego (Silesian Legion) and Marchlewskiego became Strzelców Podhalańskich (after Podhale Rifles who fought in World War I).

In subsequent years, ideologically neutral names were preferred but not as exclusively as in Český Těšín. Therefore, we see new commemorative names such as Kajzara (after Helmut Kajzar, Polish theater director), Filipowicza (after Kornel Filipowicz, Polish writer) and Hulki-Laskowskiego (after Paweł Hulka-Laskowski, a local Polish writer and journalist). As recently as 2012 Ładna Boczna (Pretty Side) was renamed to ptk. Gwido Langera (Polish World War II cryptographer with personal ties to Cieszyn). The continued use of commemorative names on the Polish side resulted in an ideologically more influenced urban toponymy, as compared to the Czech side (35\% to $21 \%$ ). The extent of renaming was, however, comparable (7\%). Polish nationalism remained the most important ideology and Christianity followed with a significant lag. Percentage of names associated with regional identity increased substantially which demonstrates the perduring historic claim to the Teschen region. This contrasts sharply with the situation in Český Těsín and leads us to formulate the following more general conclusions. See Map 9 (online, http:// projekty.osu.cz/tesinsko/mapy) for details on the post-communist period.

\section{Conclusions}

The turbulent twentieth century had a profound impact on urban toponymy everywhere in the world but we would argue that no place has been impacted more than Central Europe. Here it were not only changes of political regimes that influenced the city text but also extensive changes in the ethnic structure and state borders that transformed the larger social and (geo-) political context. Establishing toponymic hegemony under such circumstances is practically impossible because many changes occurred rapidly and almost every adult experienced several of them in his own life time. It comes as a little surprise then that official street names are often not used or even known among local inhabitants who prefer to use either abbreviated older names or names for shops, restaurants and other buildings to find their way around the city. In the case of Český Těšín, for example, names from dif- 
ferent periods such as Sachsenberg and Stalinka (officially Hlavni-Main Street), Gestapo (former seat of the Nazi Gestapo, officially Finanční úrad - the Tax Collector's Office), Leninka (Lenin's Street, officially Střelniční) and Šystot (from the German Schießstätte) and Pionyrak (Young Pioneers House) for the cultural centre officially called Strelnice remain in use. This indicates that certain over-politicisation of place names visible in current geographic literature is not necessarily substantiated in the lived practice. It is not that political regimes would not use place names strategically to gain legitimacy and silence potential opposition; so much is clear and our research clearly supports the findings of previous studies cited above. Rather, it is questionable how successful and effective those political regimes have been.

Politically-motivated toponymic changes have been documented quite extensively on examples of capitals and major cities cited above. We know significantly less about smaller towns and multilingual areas. Our research has shown that important parallels between large and small cities exists but it also suggests that certain differences can be observed. As in large cities we can say that prone to renaming are more important objects (e.g. Light 2004; GiLl 2005; AldERMAN and InwOOD 2013), objects closer to the center (e.g. Light 2004; GILL 2005), objects that already had been renamed (e.g. AZARYAHU 1997) and objects which have an ideologically motivated name (e.g. LiGHT 2004; AzARYAHU 2011). For example, the main square in Cieszyn as the most important and center-most object par excellence had eight different names during the examined period Hauptplatz (1872), Demelplatz (1894), Rynek (1920), plac Sobieskiego (1933), Adolf-Hitler-Platz (1939), Rynek (1945), Plac (Marszałka) Stalina (1946) and Rynek (1977). Even less important streets in the center had a similar fate - e.g. the current Božkova street in Český Těšín was Schmerlinggasse (1894), Široká (1925), Hinterstoisserova (1930), Batorego (1939), Dr. Hinterstoißer-Straße (1939) and Siroká (1945). The further away from the center we move, the fewer streets have commemorative names and the less frequently they were renamed. Map 10 (online, http://projekty.osu.cz/tesinsko/mapy) illustrates the extent and character of the toponymic changes in all periods.

While we have concentrated on toponymic changes, it needs to be emphasised that a substantial number of streets on both sides of the border have never been renamed, including 21 streets dating already to the Austrian period. Map 11 (online, http://projekty. osu.cz/tesinsko/mapy) shows their location and the number of periods they have survived. They are often names referring to geographical points (e.g. near-by villages and towns) or other natural features. However, in some instances this seeming ideological neutrality can be suspect. This, for example, is the case of Frysztacka street in Cieszyn dating already to the Austrian period which has never been renamed even though it refers to a Czech town which no longer exists and which was not accessible by this street for repeated periods during the twentieth century due to closed borders. We could therefore interpret this case as an expression of the Polish claim to the Czech part of the Teschen region.

The case of Teschen is an intriguing one because it is analogical to the famous separated identical twins studies in psychology. A single town was divided in two and submitted to different national, ethnic and political regimes. Our comparison shows that in spite of the contextual differences and different and changing ethnic composition, principles guiding urban toponymic politics identified in previous studies in different countries seem to 
be general rules which we might expect to find in most cases in all periods. Table 2, for example, shows a comparable intensity of renaming on both sides of the border across all periods. However, we have also identified certain differences between the two cases vis-àvis each other and between our study and other studies which are noteworthy.

Bucher et al. (2013) analysed eight Slovak cities. They found out that the use of commemorative, person-derived names in the present toponymy of these cities scored on average $52 \%$ (ranging between 36-59\%). This is significantly higher than in either Cieszyn or Český Těšín. BUCHER et al. also observed an overall prevalence of local identity with an average score of $62 \%$ (ranging between $38 \%$ and $70 \%$ ). This again contrasts sharply with either Český Těšín or Cieszyn where the national level of identification is, by far, the most important. Whether this is the result of the need to promote a strong and unambiguous national identity of the newly created border towns or whether this can be attributed to the existence of systematic differences between countries in preferred toponymic strategies will have to be established by further research.

However, also the comparison of Cieszyn and Český Těšín brings out several interesting differences. First, Polish toponymic politics has been consistently more ideological, relying to a greater extent on commemorative names than on the Czech side (see Table 3). Second, not only has the Polish town been more ideological but also it has been consistently more nationalistic (see Table 4). In both towns nationalism played a dominant role but in Cieszyn it was more important. Whether this is something specific to this contested border situation or a more general characteristic of Polish cities also remains to be determined. And third, the Polish town has been consistently keener on emphasising the local and especially the regional level of identification (see Table 5). This is partially understandable due to the fact that the historic centre of the town lies in Cieszyn. The Polish town has thus been the guardian of regional identity. However, it has been very selective in this regard. Let us remember that Cieszyn has also been more nationalistic than Český Těšín. The obvious conclusion then is that Polish nationalism was more often expressed through regional figures than Czech nationalism in Český Těšín. The regional memory expressed through Cieszyn's toponymy therefore erases Czech, German and Jewish inhabitants of the region, presenting the region as eternally and exclusively Polish. In this respect the Polish toponymic politics has been a little more insiduous than on the Czech side.

In Český Těšín, by contrast, we see a smaller use of commemorative names, less ideological fervor and a greater openness to German and Polish names. Whether this is an expression of the (in)famous Czech cynicism and Švejk-like attitude to life or whether it indicates more fundamental differences in toponymic politics between Poles and Czechs (and other countries) also remains to be determined. We may only hope that future research will shed more light on this matter.

\section{References}

Alderman D. H. (2000): Naming Places and Commemoration in the American South. In: The Professional Geographer, 52, 4, pp. 672-684. 
Alderman D. H. (2003): Street Names and the Scaling of Memory: The Politics of Commemorating Martin Luther King, Jr within the African American Community. In: Area, 35, 2, pp. $163-173$.

Alderman D. H., Inwood J. (2013): Street Naming and the Politics of Belonging: Spatial Injustices in the Toponymic Commemoration of Martin Luther King Jr. In: Social \& Cultural Geography, 14, 2, pp. 211-233.

Azaryahu M. (1996): The Power of Commemorative Street Names. In: Environment and Planning D: Society and Space, 14, pp. 311-30.

Azaryahu M. (1997): German Reunification and the Politics of Street Names: The Case of East Berlin. In: Political Geography, 16, 6, pp. 479-493.

Azaryahu M. (2011): The Politics of Commemorative Street Renaming: Berlin 1945-1948. In: Journal of Historical Geography, 37, 4, pp. 483-492.

Azaryahu M. (2012): Hebrew, Arabic, English: The Politics of Multilingual Street Signs in Israeli Cities. In: Social \& Cultural Geography, 13, 5, pp. 461-479.

Azaryahu M., Golan A. (2001): (Re)Naming the Landscape: The Formation of the Hebrew Map of Israel 1949-1960. In: Journal of Historical Geography, 27, 2, pp. 178-195.

Basso K. H. (1988): Speaking with Names: Language and Landscape Among the Western Apache. In: Cultural Anthropology, 3, 2, pp. 99-130.

Basso K. H. (1996): Wisdom Sits in Places. Landscape and Language Among the Western Apache. Albuquerque, University of New Mexico Press.

Bogoczová I. (1997): Jazyk a jeho dynamika [Language and its dynamics]. In: KadŁuBIEC K. (ed): Polská národnostní menšina na Těšínsku v České republice [Polish national minority in the Těšín region in the Czech Republic]. Ostrava, Ostravská univerzita, pp. 85-105.

BorÁk M. (1992): Těšínsko v letech 1938-1945 [The Těšín region between 1938 and 1945]. In: BorÁK M., GAWRECKi J. (eds.): Nástin dějin Těšínska [An outline of the history of the Těšín region]. Ostrava - Praha, Advertis, pp. 102-117.

BorÁK M. (2011): Těšín za války a německé okupace [The Těšín region during the war and German occupation]. In: JiRÁseK Z. et al. (eds.): Český Těšín 1920-1989: vznik a výstavba města v meziválečném období [Český Těšín 1920-1989: the creation and construction of the city during the inter-war period]. Opava, Slezská univerzita, pp. 21-41.

Borák M., GaWrecki J. (eds.) (1992): Nástin dějin Těšínska [An outline of the history of the Těšín region]. Ostrava - Praha, Advertis.

Bucher S., Matlovič R., Lukáčová A., Harizal B., Matlovičová K., Kolesárová J., Čermáková L., Michalko M. (2013): The Perception of Identity Through Urban Toponyms in the Regional Cities of Slovakia. In: Anthropological Notebooks, 19, 3, pp. 23-40.

Cenoz J., Gorter D. (2006): Linguistic Landscape and Minority Languages. In: International Journal of Multilingualism, 3, 1, pp. 67-80.

Cohen S. B., KLIOT N. (1992): Place-names in Israel's Ideological Struggle Over the Administered Territories. In: Annals of the Association of American Geographers, 82, 4, pp. 653-680.

DAVID J., MÁcha P. (2014): Názvy míst - pamět', identita, dědictví [Place names - memory, identity, heritage]. Brno, Host.

Drozdzewski D. (2014): Using History in the Streetscape to Affirm Geopolitics of Memory. In: Political Geography, 42, 1, 66-78.

GABBERT L. (2007): Distanciation and the Recontextualization of Space: Finding One's Way in a Small Western Community. In: Journal of American Folklore, 120, 476, pp. 178-203.

GAWRECKi D. (2014): Šlonzáci na Těšínsku a sčítání lidu v letech 1910 a 1921 [Šlonzaks in the Těšín region and the population censuses in 1910 and 1921]. In: Těšínsko: vlastivědný časopis, 57,1 , pp. 1-9 
Gill G. (2005): Changing Symbols: The Renovation of Moscow Place Names. In: The Russian Review, 64, 3, pp. 480-503.

González Faraco J. C., Murphy M. D. (1997): Street Names and Political Regimes in an Andalusian Town. In: Ethnology, 36, 2, pp. 123-148.

Harley J. B. (1988): Maps, Knowledge and Power. In: Cosgrove D., Daniels S. (eds.): The Iconography of Landscape. Cambridge, Cambridge University Press, pp. 277-312.

Hauser M. (1872): Situationsplan von der Stadt Teschen [City map of Těšín]. Leipzig, V. Brockhaus.

Herman D. (1999): The Aloha State: Place Names and the Anti-conquest of Hawai'i. In: Annals of the Association of American Geographers, 89, 1, pp. 76-102.

Horsman S. (2006): The Politics of Toponyms in the Pamir Mountains. In: Area, 38, 3, pp. 279291.

JoRdAN P. (2009): Place Names as Ingredients of Space-related Identity. In: JordAN P., BerGmann H., Cheetham C., Hausner I. (eds.): Geographical Names as a Part of the Cultural Heritage. Wien, Institut für Geographie und Regionalforschung der Universität Wien, Kartographie und Geoinformation, pp. 33-39 (= Wiener Schriften zur Geographie und Kartographie, 18).

KADŁubiec K. et al. (1997): Polská národnostní menšina na Těšínsku v České republice [The Polish national minority in the Těšín region in the Czech Republic]. Ostrava, Ostravská univerzita.

Kamusella T. (2007): Silesia and Central European Nationalisms: The Emergence of National and Ethnic Groups in Prussian Silesia and Austrian Silesia, 1848-1918. West Lafayette, Purdue University Press.

KRŮL M. (2011): Ustanovení úředního názvu Český Těšín [On the institutionalisation of the official name of Český Těšín]. In: JiRÁseK, Z. et al. (eds.): Český Těšín 1920-1989: vznik a výstavba města v meziválečném období [Český Těšín 1920-1989: the creation and construction of the city during the inter-war period]. Opava, Slezská univerzita, pp. 106-113.

Light D. (2004): Street Names in Bucharest, 1990-1997: Exploring the Modern Historical Geographies of Post-socialist Change. In: Journal of Historical Geography, 30, 1, pp. 154-172.

LuTTERER I., ŠrÁMEK R. (2004): Zeměpisná jména v Čechách, na Moravě a ve Slezsku [Geograpical name in Bohemia, Moravia and Silesia]. Havlíčkův Brod, Tobiáš, $2^{\text {nd }}$ edition.

Marten H., van Mensel L., Gorter D. (2012): Studying Minority Languages in the Linguistic Landscape. In: Gorter D., Marten H., van Mensel, L. (eds.): Minority Languages in the Linguistic Landscape. New York, Palgrave MacMillan, pp. 1-15.

NASH C. (1999): Irish Placenames: Post-Colonial Locations. In: Transactions of the Institute of British Geographers, 24, 4, pp. 457-480.

Oliveira K. R., Wahi A. K. (2009): Place Names as Vehicles of Ancestral Memory. In: AlterNative, 5, 2, pp. 101-115.

Palonen E. (2008): The City-text in Post-communist Budapest: Street Names, Memorials, and the Politics of Commemoration. In: GeoJournal, 73, 3, pp. 219-230.

Patryn, L. (ed.) (1912): Die Ergebnisse der Volkszählung vom 31. Dezember 1910 in Schlesien [Results of the population census in Silesia in December 31, 1910]. Troppau, Verlag des Schlesischen Landesausschusses, pp. 58-59.

PuZey G. (2009): Opportunity or Threat? The Role of Minority Toponyms in the Linguistic Landscape. In: Ahrens W., Embleton S., Lapierre A. (eds.): Names in Multi-Lingual, Multi-Cultural and Multi-Ethnic Contact. Proceedings of the $23^{\text {rd }}$ International Congress of Onomastic Sciences August 17-22, 2008, York University, Toronto, Canada. Toronto, York University, pp. 821-827. - http://yorkspace.library.yorku.ca/xmlui/handle/10315/4022 (accessed Sept. 30, 2018). 
Rose-Redwood R., Alderman D., Azaryahu M. (2010): Geographies of Toponymic Inscription: New Directions in Critical Place-name Studies. In: Progress in Human Geography, 34, 4, pp. 453-470.

SiweK T. (1996): Česko-polská etnická hranice [The Czech-Polish ethnic boundary]. Ostrava, Filosofická fakulta Ostravské univerzity.

STUDNICKi G. (2015): Śląsk Cieszyński: obrazy prześłosczi i tożsamość miejsc i ludzi [Těšín, Silesia: images of history and identity of places and people]. Katowice, Wydawnictvo Universytetu Śląskiego.

ŠAkahja L., Stanić J. (2011): Other(ing), Self(portraying), Negotiating: The Spatial Codification of Values in Zagreb's City-text. In: Cultural geographies, 18, 4, pp. 495-516.

Szabó Gilinger E., Sloboda M., Šimičić L., Vigers D. (2012): Discourse Coalitions For and Against Minority Languages on Signs: Linguistic Landscape as a Social Issue. In: GoRTER D., Marten H., van Mensel L. (eds.): Minority Languages in the Linguistic Landscape. New York, Palgrave MacMillan, pp. 263-280.

Thornton T. (1997a): Know Your Place: The Organization of Tlingit Geographic Knowledge. In: Ethnology, 36, 4, pp. 295-307.

Thornton T. (1997b): Anthropological Studies of Native American Place Naming. In: American Indian Quarterly, 21, 2, pp. 209-228.

TuAn, Y.-F. (1991): Language and the Making of Place: A Narrative-Descriptive Approach. In: Annals of the Association of American Geographers, 81, 4, pp. 684-696.

Yeон B. S. A. (1996): Street-naming and Nation-building: Toponymic Inscriptions of Nationhood in Singapore. In: Area, 28, 3, pp. 298-307.

ZAHRADNIK S. (1992): Národnostní struktura na Záolží podle výsledků sčítání lidu (1880-1991) [The national composition of Zaolzie according to the results of the population census (1880-1991)]. In: BorÁk M., GAwrecki J. (eds.): Nástin dějin Těšínska [An outline of the history of the Těšín region]. Ostrava - Praha, Advertis, pp.159-261. 